\title{
FOUND IN TRANSLATION - DISCOURSE MARKERS OUT OF THE BLUE
}

\author{
KJETIL RA HAUGE \\ University of Oslo
}

ABSTRACT

On the basis of literary translations, this study provides examples of how the function of discourse markers in a given language, in this case Bulgarian, can be better understood by examining cases where there is no discourse marker in the original, but one has been added by the translator. Clues to its function and validation of earlier analyses may then be found in the text and context of the original.

\section{[1] DISCOURSE MARKERS}

Discourse markers (hereafter DMs), also called pragmatic markers and modal markers (or, for those of them that are indeclinable particles: pragmatic particles and modal particles), are words similar to the English well, kinda, oh, but and the Bulgarian be, abe, ami, ama, de, etc. Typical properties of DMs are that while they have no semantic content ("meaning"), they do have functions, they do not affect the truth value of the utterance, they cannot constitute an utterance by themselves (as opposed to interjections). They are often derived from (or even homophonous with) words with semantic content (oh and ami are also interjections) or grammatical function (but and ami are also interjections). For a more detailed description based on German particles see Winters (2013, esp. pp. 429-434). Functions of DMs include indication of change of topic, of turn-taking in conversation, increase or attenuation of the perlocutionary effect of the utterance, and signalling aspects of the informational status of the utterance.

Inventories of DMs differ from language to language: language A may have no equivalent to a given DM in language $B$ but will express the same function through lexical means. For instance, there is no direct equivalent in English for German and Nordic markers indicating shared knowledge. In English, they are sometimes translated by a tag question:

(1) a. Ich habe es ja dir gesagt! [German]

b. Jeg har jo fortalt deg det! [Norwegian]

c. I told you, didn't I? 
Even when two languages have cognate DMs, their functions may differ. For instance, Hasselgård (2004) showed a high degree of non-correspondence between the English DM now and its Norwegian cognate nå.

As the study of discourse markers dates back only to the last decades of the twentieth century, it has not been sufficiently incorporated into lexicography, and many dictionaries are unreliable when it comes to explaining DMs. Dictionary definitions often strive to assign "meaning" to DMs, and this leads to the context being reinterpreted as meaning, and often to contradictory meanings for one and the same marker (e.g., 'discontent' and 'satisfaction'), as in the following example from the standard one-volume dictionary of Russian (Ožegov \& Švedova 2006):

(2) Nu da (razg.) - upotr. dlja vyraženija: 1) podčerknutogo podtverždenija, soglasija. [...] 2) nedoverija, nesoglasija, somnenija.

'Nu da (coll.) - used to express: 1) emphatic confirmation, agreement. [...] 2) disbelief, disagreement, doubt'

[my translation, as all translations hence, except where noted].

Analyzing the functions of DMs is not an easy task, even for native speakers, and analyzing DMs in a foreign language even harder. The non-native linguist has to rely on acquired intuitions and check them against native intuitions. Fischer (1998) has proposed to use diagnostic contexts ("test-frames") for testing the validity of analyses, and Spenader $(2004,9)$ has shown how " $t]$ he multiple functions of some markers can potentially be illuminated by examining how they are rendered in translation" using a large parallel corpus. The strategy we are going to use here is the opposite of Spenader's: we shall examine how DMs occur in translations when there is no DM in the original. Post $(2010,424-427)$ has shown how insights about the functions of discourse markers can be attained in such cases, but here we shall concentrate on demonstrating how these cases can be used for validating previous analyses. The sources are translations into Bulgarian of dialogue-rich literary works: children's books, plays, science fiction, detective and adventure novels. Translations and originals were harvested from Internet sources and to some extent paper-based originals were used where electronic versions are not available.

In principle, there are four ways a DM in a translation can relate to the original. To illustrate them, we shall use a string of classic typographer's dummy text to represent the original, and a sequence of the Bulgarian equivalent of "blah blah, yadda yadda" to represent the translation, with "DM" standing in for any discourse marker and the zero item " $\varnothing$ " standing for omitted text in the translation: 
(3)

TYPE 1. DM IN TRANSLATION AND ORIGINAL

Lorem ipsum dolor sit amet, DM consectetur adipiscing elit.

Ala bala drăn drăn alabala drăn drăn, DM bala drăn drăn alabala.

These cases will either confirm the translations given in existing bilingual lexicographic works or, if deviations from them are sufficiently numerous, indicate a neccessity for revision.

(4) TYPE 2. LEXICAL MATERIAL IN ORIGINAL TRIGGERS DM AND IS RETAINED

Lorem ipsum dolor sit amet, consectetur adipiscing elit.

Ala bala drăn drăn alabala drăn drăn, DM bala drăn drăn alabala.

These cases may provide validation as long as the lexical material in question fits in with the analysis under scrutiny.

TYPE 3. DM TRIGGERED BY GENERAL CONTEXT OF ORIGINAL

.. hendrerit neque. Lorem ipsum dolor sit amet, consectetur adipiscing elit. Mauris bibendum ...

... . drăn. Ala bala drăn drăn alabala drăn drăn, DM bala drăn drăn alabala. Ala...

(6) TYPE 4. LEXICAL MATERIAL IN ORIGINAL TRIGGERS DM AND IS NOT RETAINED

Lorem ipsum dolor sit amet, consectetur adipiscing elit.

Ala bala drăn drăn alabala, $\varnothing$ DM bala drăn drăn alabala.

Type 2, 3, and 4 can all be assumed to represent cases where the translator has considered that the text needs a DM in Bulgarian, in spite of there being none in the original. Under type 4 , the translator may have considered the triggering lexical material to have become superfluous after the addition of the DM, and we thus get a precise indication of what the triggering element is.

Our hypothesis is then that translations may provide validation of analyses if a DM in a translation into language A does not correspond to a DM in the original language B, but is either expressed by lexical means, or definitely implicated by the context. To put it another way, we are looking for translations into Bulgarian where the translator has felt that his translation calls for the use of a DM, regardless of the fact that there is none in the original. We have to assume that translators are competent and translate in an adequate way, but we keep an eye open for literal translations.

For the marker $\check{c} e$ it was claimed in Hauge $2007 \mathrm{~b}$ that it is used by the speaker in statements and rhetorical questions to indicate that the hearer in a previous utterance has failed to take into account information that according to the speaker should be available to him, in other words, has asked a "stupid question".

The following example is from an original Bulgarian text: 
(7) “Dimo ne si li e došăl?” “Če kak šte si dojde, nali e vojnik?” izpravi se Dimovica.

“"Hasn't Dimo come?" “ČE how could he come, he’s serving in the military, right?" said Dimo's wife, getting up.' [KP79]

In this example, the discourse marker nali indicates that the speaker assumes that the propositional content of the utterance is known to the conversation partner, much in the same way as German ja, Swedish ju and Norwegian and Danish jo. The marker $\check{c}$ e further gives indication that the speaker considers that the interlocutor has not taken that information into consideration in a recent utterance. Examples with motivating text (shown in italics) in the original: ${ }^{1}$

(8) a. "Nu a kto že? Kto?" laskovo sprosil Igor' Petrovič. "Otkuda mne znat'? Éto vy dolžny znat' - kto!"

b. "Dobre, a koj? Koj?” laskavo popita Igor Petrovič. “Če otkăde da znam? Vie trjabva da znaete koj!" [SS79]

"“Then who did? Who?" Zykov asked gently. "How should I know? You should know who!"”2

(9) a. "So sagen Sie mich wenigstens, wie wir die Knochens fortbringen wollen?" "Wie soll ich das wissen? Ich möchte mich da auf deinen Scharfsinn verlassen." b. "Kažete mi pone kak šte prenesem kostite." "Če otkăde da znam? Šte razčitam na tvojata săobrazitelnost." [KM82]

"“Then, at least tell me: how are we to transport the bones?" "How should I know? I shall rely on your cunning in this case."'3

(10) a. "Detritus, why the hell did you put them in the cells?" said Vimes wearily. "What else we got, sir? Dey're not locked in and dey got clean blankets."

b. "Detritus, zašto, po djavolite, si gi zatvoril v kiliite?" otpadnalo popita Vajms. "Če kăde da gi nastanja, săr? Ne sa zaključeni i im dadoch čisti odeala." [PT00]

(11) a. "Et nos armes, lui demandai-je, nos fusils?" "Des fusils! à quoi bon? Vos montagnards n'attaquent-ils pas l'ours un poignard à la main, et l'acier n'est-il pas plus sûr que le plomb?"

b. "A orăžieto," rekoch az, "puškite ni!" "Puškite li? Če za kakvo vi sa? Migar planincite po vašite mesta ne napadat mečkite samo s nož v răka i stomanata ne e li po-sigurna ot kuršuma?" [ŽV77]

“"And our arms?" asked I; "our guns?" "Guns! What for? Do not moun-

[1] Translations into English below are mine unless otherwise indicated and aim to represent the original rather than the Bulgarian translation, and wherever possible I have used published English translations.

[2] English translation from Definitely Maybe, trans. by Antonia W. Bouis, Melville House Publishing 2014.

[3] The Inca's Legacy, trans. by Marlies Bugmann, independently published by the translator, 2009. 
taineers attack the bear with a dagger in their hand, and is not steel surer than lead?"'4

A similar function is described for German doch by (Karagjosova 2004, ch. 5): "Maria kommt mit." "Sie ist doch verreist" ("Maria will join us." "But she has gone away.").

Examples with lexical material in original, omitted in favour of DM:

a. "Know a model named Sondra Lee?" I said. "Sonny? Of course, any photographer would know Sonny. She's the top model on the coast."

b. "Poznavaš li Sondra Lij? Tja e fotomodel." "Soni li? Če $\varnothing$ koj fotograf ne ja poznava? Tja e model nomer edno na Zapadnoto krajbrežie." [RČ91]

a. "Small Hunters? Ah, feine Erbschaft! Einige Millionen! Ich war Verweser. [...] Habe sie leider aufgeben müssen. Wollte, die Angelegenheit wäre nicht so schnell zu Ende gegangen." "Zu Ende? Ihr wollt doch nicht etwa damit sagen, daß die Sache erledigt ist?" "Was sonst? Natürlich habe ich das damit sagen wollen." "Erledigt?" fragte ich erschrocken.

b. "Smol Chăntăr? A-a, chubavo nasledstvo! Njakolko miliona! Az bjach negov upravitel. [...] Za săžalenie trjabvaše da ja prekratja. Šteše mi se vsičko da ne beše svăršilo tolkova bărzo." "Svăršilo li e? Da ne bi da iskate da kažete, če slučajat e priključen?" "Če kakvo drugo? Ø" "Priključen?" popitach izplašeno. [KM96]

"'Small Hunter? Ah, a fine inheritance! Several millons! I was the executor. [...] Had to give it up, unfortunately. Had hoped the matter would not come to an end so soon." "Ended? But you don't mean to say that the case is closed?" "What else? Of course I meant to say that." "Closed?" I asked, terrified.'

As pointed out in Hauge 2007a, $\check{c} e$ in exclamations and in non-rhetorical, information-seeking questions indicates that the exclamation or question arises from an unexpected and sudden revision of the speaker's knowledge, i.e., what in everyday parlance is termed a surprise, as in this original Bulgarian example:

“O-o! Bor'o!” izvika gospožata. “Če kakvo praviš tuk samičăk?” [KK40]

“"Oh! Borjo!" the lady called out. "ČE what are you doing here all alone?"

We find that translators exploit this function as well:

(15) “Has he come?" "No," says her husband. "Good-NESS gracious!" she says, "what in the warld [sic, MT's imitation of Afro-American pronunciation]

[4] 20,000 Leagues under the Sea, trans. by Lewis Mercier, 1872. http://www . gutenberg. org/ebooks/164, accessed 15 June, 2014. 
can have become of him?"

"Dojde li?" "Ne," reče toj. "Gooos-podi!" vikna tja. "Če kakvo li mu se e slučilo?" [MT65]

(16) "So where'd you get the picture, Sailor?" Garcia said. [...] "Lola Faithful had it and stashed it in Union Station. I found the receipt in her house." "How come the cops didn't find it?" Garcia said.

"Ta otkăde, kaza, če ja imaš tazi snimka? [...]" "Lola Fejtful ja beše skrila na Juniăn Stejšăn. Otkrich razpiskata v doma j." "Če policaite kak taka sa ja propusnali?" [RČ91]

(17) "Who're all these people?" "Watchmen, sir. You appointed them." "Did I? I haven't even met some of them!" "You signed the paperwork, sir. And you sign the wage bill every month."

"Kakvi sa vsičkite tija chora?" "Policai, săr. Vie ste gi naznačaval." “Taka li săm napravil? Če az dori ne săm viždal njakoi ot tjach!" "Vie parafirachte dokumentite im, săr. I vseki mesec podpisvate vedomostta za zaplatite im." [PT00]

The marker abe, often spelled $a$ be, according to Tiševa \& Hauge (2004), is used when there is a clash of interest between the participants of the speech situation for the continued development of events in the real world. Specifically, it is used by speaker A when A knows that speaker B has a different agenda from speaker A. It can be illustrated by the following silly joke from a Bulgarian Internet portal:

(18) Dva drakona razgovarjat. Po edno vreme edinijat kazva: “Abe - ja mlăkni malko, če mi stana gorešto."

'Two dragons are having a conversation. Then one of them says: "Shut up for a while, won't you, I think it's getting hot in here."

It is usually not hard to spot the agenda conflict in the cases where we find abe in the translation. The speaker who uses this DM in the first example below has been aggressively challenged by his interlocutor to confirm his trust in him and instead of answering a direct question resorts to explaining away things:

(19) “Señor?" His voice was soft, but icy. "You doubt my word?" "You guys are always talking about honor. Honor is the cloak of thieves - sometimes."

"Sen'or?" Glasăt mu prozvuča meko, no ledeno-studeno. "Nima postavjate dumite mi pod sămnenie?" "Abe vie, latinoamerikancite, samo za čest govorite. A čestta e prikritie za mošenicite - ponjakoga.” [RČ54]

(20) “[...] It's the system. Maybe it's the best we can get, but it still ain't any Ivory Soap deal." "You sound like a Red," I said, just to needle him. "[...] Takava ni e sistemata. Može da e naj-dobrata, kojato zaslužavame, 
no ot nikoe položenie ne e idealna." "Abe ti govoriš kato njakoj červen," kazach az, kolkoto da go klăvna. [RČ54]

$$
\begin{aligned}
& \text { "Are you gonna show your ass every day at lunch?" asked Frank Herrera, a } \\
& \text { retired colonel from somewhere up North. } \\
& \text { "Abe, ti vseki den li šte ni se perčiš po objad?" zapita Frank Cherera, sev- } \\
& \text { ernjak i polkovnik ot zapasa. [GD82] }
\end{aligned}
$$

Tiševa \& Hauge (2004, 263-264) also describe a function where the clash of agendas is on the meta-level and consists in the question of whether a conversation is to be entered into or not; specifically, when speaker A wants to engage in communication with person $B$, but assumes that person $B$ is not interested in engaging in communication. Other languages may use lexical or morphological means for the same purpose. In the Czech example below, the speaker calls for the prospective interlocutor's attention by using his surname in the vocative case prepended by the second person singular personal pronoun; a mechanism that is not available to the Bulgarian translator.

(22) “[...] Šak váš nebožtik muž, Prouzko, dej mu Pámbu věčnou slávu, von byl teda jako duchař a spirita, a já mu jednou poudám z legrace: 'Ty, Prouzo, zavolej mně nazpátek toho zlýho ducha, co mně vyklouz,' a von se na to dožere a až do svý smrti na mě nepromluvil. [...]”

“To i tvoja pokojnija măž, Prouzice, leka mu prăst, toj nali beše spiritist i vikaše duchovete, vikam mu az edin păt na majtap: A be, Prouza, ja mi izvikaj nazad dušata, deto si ja izpusnach, a toj vze, če se dokači i do smărtta si ne mi progovori." [KČs1]

"'Your dead husband though, Mrs. Prouza, may he rest in peace, he was always a thoughtful and spiritual man, and I said to him one day, just as a joke like, 'Here, Prouza, call back that evil spirit of mine, it's escaped again!' And he took it seriously and from that day on he never spoke another word to me." 5

In the following example, one of the speakers in a telephone conversation has indicated that the exchange is concluded on his behalf, and the other one seems have followed suit, but suddenly finds it necessary to reopen the conversation:

(23) "Vodka u tebja est'?" "Vrode byla. Dve butylki." "Možeš' smelo vypit'. S ètoj mantroj očen' chorošo. Čerez čas vse projdet. Zavtra pozvonju." "Spasibo. Slušaj, a kto èto tam plačet?" "Syn," otvetil Gireev.

"Vodka imaš li?" "Maj imam. Dve butilki." "Možeš da si pijneš. S tazi mantra vliza mnogo dobre. Sled čas šte ti mine. Utre šte ti se obadja."

[5] The Absolute at Large, trans. by David Wyllie, 2010, at http://www.finitesite.com/dandelion/ webtrans.html, accessed 15 June, 2014. 
“Mnogo ti blagodarja. A be, koj plače tam pri tebe?" "Sinăt mi," otgovori Gireev. [PV02]

"'Have you got any vodka?" "I think I had two bottles." "You can drink them both. It goes well with this mantra. In an hour it'll be all over. I'll call you tomorrow." "Thanks. Listen, who's that crying there?" "My son", Gireiev answered. ${ }^{6}$

\section{[2] CONCLUSION}

There are certainly discourse markers to be found in translations, and some of them unsupported by equivalent markers in the originals. The few examples we have shown here have served to validate existing analyses, but as shown by Post (2010) we can also gain new insights by studying these cases.

\section{PRIMARY SOURCES}

RČ54 Čandlăr, Rejmănd. 1983. Dălgoto sboguvane (Raymond Chandler, The Long Goodbye, 1954). Translated by Žečka Georgieva.

RČ91 Čandlăr, Rejmănd; Robărt B. Parkăr. 1991. Pudăl Springs (Raymond Chandler, Robert B. Parker, Poodle Springs, 1989). Translated by Žečka Georgieva.

KČ81 Čapek, Karel. 1981. Fabrika za absoljut (Tovarna na absolutno, 1922). Translated by Svetomir Ivančev and Jasen Ivančev.

GD82 Grišam, Džon. 2002. Prisădata (John Grisham, The Runaway Jury, 1996). Translated by Ljubomir Nikolov.

KK40 Konstantinov, Konstantin. 1940. Sedem časăt zaranta, p. 94. Obšt archiv, card catalogue at Institute for Bulgarian Language, Bulgarian Academy of Sciences.

KM82 Maj, Karl. 1989. Zaveštanieto na inkata (Karl May, Das Vermächtnis des Inka, 1891-1892). Translated by Veselin Radkov.

KM96 Maj, Karl. 1996. Satana i Juda (Karl May, Satan und Ischariot, 1896-1897). Translated by Veselin Radkov.

MT65 Mark Tven. 1965. Priključenijata na Chăkălberi Fin (Mark Twain, The Adventures of Huckleberry Finn, 1884). Translated by Nevjana Rozeva.

PV02 Pelevin, Viktor. 2002. Generation "P" (Generation "P”, 1999). Translated by Ivan Totomanov.

[6] Homo Zapiens, trans. by Andrew Bromfield, Penguin Books 2002. 
KP79 Petkanov, Konstantin. 1979. Morava zvezda kărvava, p. 250. Obšt archiv, card catalogue at Institute for Bulgarian Language, Bulgarian Academy of Sciences.

PT00 Pratčet, Teri. 2000. Šovinist (Terry Pratchett, Jingo, 1997). Translated by Elena Paskaleva.

SS87 Strugacki, Arkadij; Boris Strugacki. 1987. Miliard godini do svăršeka na sveta (Za milliard let do konca sveta, 1977). Translated by Milan Asadurov.

ŽV77 Vern, Žul. 1977. Kapitan Nemo (Jules Verne, Vingt Mille Lieues sous les mers, 1870). Translated by Konstantin Konstantinov.

\section{REFERENCES}

Fischer, Kerstin. 1998. Validating semantic analyses of discourse particles. Journal of Pragmatics 29. 111-127.

Hasselgård, Hilde. 2004. 'Not now' - on non-cognate correspondence between the cognate adverbs now and nå. SPRIKreports: Reports of the project Languages in Contrast (Språk $i$ kontrast) 20. http://www.hf .uio.no/ilos/forskning/ prosjekter/sprik/pdf/hh/HasselgaardReport20.pdf.

Hauge, Kjetil Rå. 2007a. Dumme spørsmål og hvordan de besvares på bulgarsk: Den pragmatiske partikkelen $\check{c}$. Oral presentation at the Seventeenth meeting of Nordic Slavists, Copenhagen 6-11 August 2007.

Hauge, Kjetil Rå. 2007b. Stupid questions and things I should not have to tell you to do: A Bulgarian pragmatic marker for not quite shared knowledge. In Proceedings from Formal approaches to the South Slavic and Balkan Languages, 122-125. Sofia.

Karagjosova, Elena. 2004. The meaning and function of German modal particles. Saarbrücken dissertations in computational linguistics and language technology.

Ožegov, S. I. \& N. Ju. Švedova. 2006. Tolkovyj slovar' russkogo jazyka. BITI Technologii.

Post, Margje. 2010. A contrastive analysis of Russian and Norwegian utteranceinitial coordinating conjunctions. Oslo studies in language 2. 413-432.

Spenader, Jennifer. 2004. Using simple word alignment measures to study discourse particles. Sprache und Datenverarbeitung, International journal for language data processing 28.9-19. http://www.ai.rug.nl/ spenader/public_docs/ Spenader_2004_Discourse_Particles.pdf. 
Tiševa, Jovka \& Kjetil Rå Hauge. 2004. Časticata 'abe' kato pragmatičen marker. Problemi na bălgarskata razgovorna reč 6. 255-266.

Winters, Marion. 2013. German modal particles - from lice in the fur of our language to manifestations of translators' styles. Perspectives: Studies in translatology $21.427-445$.

AUTHOR CONTACT INFORMATION

Kjetil Rå Hauge

Department of Literature, Area Studies and European Languages

University of Oslo

Norway

k.r.hauge@ilos.uio.no 